\title{
Determinan pemberian Asi Eksklusif pada Ibu Bekerja di Instansi Pemerintah Kabupaten Bungo Provinsi Jambi
}

\author{
Evi kristina ${ }^{1}$, Iskandar syarif ${ }^{2}$, Yuniar Lestari ${ }^{3}$ \\ Prodi S2 Kebidanan Fakultas Kedoteran Universitas Andalas \\ Email:vie_cristina@yahoo.com
}

\begin{abstract}
The role of a mother in maintaining a child's health is very important. Knowledge, attitude, motivation, availability of health care facilities, behavior of health workers influence the formation of health behaviors. This study aims to analyze the factors that are related and the most dominant towards exclusive breastfeeding for mothers working in Government Agencies in Bungo Regency. This study uses a combination of quantitative and qualitative research methods. Quantitative research uses cross sectional design. The sample in the quantitative study was 50 mothers who had babies> 6-12 months, while in qualitative research there were 6 in-depth interviews with the heads of the Bungo District Government Agencies. The results of the study obtained the proportion of exclusive breastfeeding as much as 34\%. Factors related to breastfeeding are birth attendants and caregiver / family support and the most dominant in exclusive breastfeeding for working mothers is the support of caregivers / family. The scope of exclusive breastfeeding has not reached the target of $80 \%$ of the targets set by the Government due to lack of support from Government Agencies, health workers and from caregivers / families. Various efforts are needed to improve the achievement of coverage of exclusive breastfeeding, especially through supporting facilities to support exclusive breastfeeding and the optimization of the role of the Health Office.
\end{abstract}

Keywords:

exclusive breastfeeding, working mother

\section{PENDAHULUAN}

Keberhasilan

dari pembangunan

kesehatan dapat dilihat dari berbagai indikator yang digunakan untuk memantau derajat kesehatan sekaligus sebagai evaluasi keberhasilan pelaksanaan program. Indikator untuk menilai derajat kesehatan tersebut yaitu dapat dilihat dari mortalitas, status gizi dan morbiditas. Masalah kematian ibu dan bayi di Indonesia masih merupakan masalah besar bagi bangsa. Survei Demografi Kesehatan Indonesia (SDKI) tahun 2012 Angka Kematian Bayi (AKB) 32 per 1000 kelahiran hidup, Pada tahun 2015 berdasarkan data SUPAS AKB 22,23/1000 kelahiran hidup ditargetkan AKB menjadi 24 per 1000 kelahiran hidup.

Air susu ibu (ASI) merupakan makanan pertama, utama dan terbaik bagi bayi. ASI merupakan nutrisi ideal yang sangat bermanfaat untuk kesehatan bayi karena mengandung zat perlindungan terhadap berbagai penyakit. Nilai gizi dalam ASI lebih besar dibandingkan dengan susu formula karena didalam ASI mengandung lemak, karbohidrat, protein, dan air dalam jumlah yang tepat untuk pencernaan, pertumbuhan dan perkembangan otak bayi. Kandungan nutrisi yang ada dalam ASI memiliki keunggulan yang tidak dapat ditiru oleh susu formula.

Badan kesehatan dunia, World Health Organization (WHO), merekomendasikan bayi mendapat ASI ekslusif, yaitu memberikan hanya ASI saja tanpa memberikan makanan dan minuman lain kepada bayi sejak lahir sampai berumur enam bulan, kecuali obat dan vitamin, namun bukan berarti setelah pemberian ASI eksklusif selesai pemberian ASI dihentikan, akan tetapi ASI tetap diberikan sampai bayi berusia dua tahun.

Data pada tahun 2012 berdasarkan dari United Nations Children's Fund (UNICEF), hanya sekitar 39\% ibu yang memberikan ASI secara eksklusif di seluruh dunia dan pada tahun 2015 , hanya $40 \%$ yang memberikan ASI Eksklusif. Cina yang merupakan salah satu negara yang jumlah penduduknya cukup besar di dunia, hanya $28 \%$ bayi yang diberikan ASI secara Eksklusif, sedangkan Kamboja berhasil meningkatkan angka pemberian ASI eksklusif untuk anak usia dibawah 6 bulan secara drastis dari $11,7 \%$ pada tahun 2000 menjadi $74 \%$ pada tahun 2010. Negara lain seperti Tunisia memberikan kabar buruk dalam waktu satu dekade terakhir, dimana persentase pemberian ASI eksklusif mengalami penurunan yang sangat drastis yaitu dari $45.6 \%$ turun menjadi $6.2 \%$, sedangkan negara-negara yang menduduki posisi tiga angka pemberian ASI eksklusif terendah didunia adalah Somalia, Chad dan Afrika Selatan. Perkembangan otak anak sekitar delapan puluh persen dimulai sejak dalam kandungan sampai usia tiga tahun yang dikenal dengan periode emas, oleh karena itu diperlukan pemberian ASI eksklusif selama enam bulan dan dapat diteruskan sampai anak berusia dua tahun. Hal tersebut dikarenakan ASI mengandung protein, karbohidrat, lemak dan mineral yang dibutuhkan bayi dalam jumlah yang seimbang.

Pemberian ASI eksklusif di Indonesia juga masih kurang bahkan menurun, berdasarkan 
Riset Kesehatan Dasar (Riskesda) pada tahun 2013, menyebut bahwa pada tahun 2011 hanya $15,3 \%$ anak di Indonesia yang mendapatkan ASI eksklusif, sedangkan pada tahun 2012 pemberian ASI eksklusif di Indonesia mencapai angka 42\%, meningkatnya persentase pemberian ASI eksklusif hanya berkisar $27,5 \%$. Perhitungan persentase ASI eksklusif yang terbaru berdasarkan data Riskesda tahun 2013, keberhasilan pemberian ASI eksklusif hanya sebesar $54.3 \%$. Data yang diperoleh dari pusat data dan Informasi Kementerian Kesehatan Republik Indonesia tahun 2014. persentase terbaru pemberian ASI eksklusif pada tahun 2014 hanya $33,6 \%$. Persentase pemberian ASI eksklusif secara nasional diperoleh angka tertinggi terdapat pada Provinsi Nusa Tenggara Barat yaitu $79.7 \%$, sedangkan persentase terendah terdapat pada Provinsi Maluku yaitu $25,2 \%$. Provinsi Jambi menduduki urutan ke 11 terendah dalam cakupan pemberian ASI eksklusif, yaitu sebesar $51.3 \%$. Jumlah tersebut belum memenuhi target pemberian ASI eksklusif yang ditetapkan secara nasional oleh pemerintah yaitu $80 \%$ dari jumlah bayi yang ada di Indonesia.

Faktor-faktor yang menyebabkan ibu tidak memberikan ASI Eksklusif pada ibu yang bekerja dikarenakan pengetahuan tentang menyusui yang benar, perlengkapan memerah ASI, dan dukungan tempat kerja. Masalah pada ibu bekerja dikarenakan tidak ada waktu untuk memberikan ASI secara langsung oleh karena itu ibu dapat menyimpan ASI yang telah diperah sebelumnya untuk diberikan kepada bayinya. (Gibney et al., 2008). Hasil penelitian di Brazil, dari 111 kota di Brazil menunjukkan hanya $13,9 \%$ ibu yang memberikan ASI Eksklusif kepada bayinya. Penelitian yang dilakukan di Singapura, para ibu berhenti untuk menyusui dikarenakan saat ibu kembali untuk bekerja karena tidak mampu menyeimbangkan tuntutan pekerjaannya.

Penelitian yang dilakukan pada tahun 2009 di Purwokerto Jawa Tengah, dilakukan pada karyawan Perguruan tinggi Negri menunjukkan bahwa hanya $21 \%$ ibu yang memberikan ASI Eksklusif kepada bayinya, kegagalan tersebut disebabkan karena sikap ibu terhadap pemberian ASI Eksklusif dan peraturan di tempat kerja. (Rahardjo \& Dyah, 2009). Penelitian Afriana (2004) Di Instansi Pemerintah DKI Jakarta menunjukkan bahwa hanya $28 \%$ ibu bekerja yang memberikan ASI Eksklusif. Hasil yang senada ditemukan pada penelitian Fauzie (2006) Di Jakarta ditemukan hanya 38\% ibu bekerja yang memberikan ASI Eksklusif kepada bayinya.

Hasil penelitian yang dilakukan Rohani (2010) tentang faktor-faktor yang meningkatkan risiko kegagalan pemberian ASI eksklusif pada ibu yang bekerja di kota Mataram didapatkan hasil bahwa, yang terbukti berpengaruh secara signifikan terhadap pemberian ASI eksklusif yaitu, persepsi yang keliru, tingkat pengetahuan ibu yang kurang dan berdasarkan besaran nilai OR menunjukkan bahwa ibu bekerja memiliki risiko kegagalan pemberian ASI eksklusif sebesar 10 kali lebih besar dibandingkan dengan ibu tidak bekerja ${ }^{(7)}$

Penelitian Haryani pada tahun 2014 mengenai alasan tidak diberikannya ASI ekskusif oleh ibu bekerja di Kota Mataram Nusa Tenggara Barat, antara lain karena adanya rasa malas dari ibu, beban kerja yang tinggi, waktu cuti terbatas, sarana dan prasarana yang kurang, dan tututan ekonami keluarga. Sedangkan hal-hal yang menghambat ibu bekerja di dalam pemberian ASI eksklusif pada bayi dipengaruhi oleh faktor pengetahuan dan faktor kurangnya informasi.

Data yang diperoleh dari SDKI pada tahun 2007, 95\% ibu di Indonesia pernah untuk menyusui bayinya. Pemerintah mentargetkan $80 \%$ cakupan ASI Eksklusif yang akan dicapai, akan tetapi hanya $15,3 \%$ ibu yang memberikan ASI secara Eksklusif kepada bayinya. Prevalensi pemberian ASI Eksklusif cenderung menurun dengan berbagai alasan, salah satunya karena ibu bekerja.

Indonesia telah menerbitkan Peraturan Pemerintah Nomor 33 Tahun 2013 tentang pemberian ASI eksklusif sebagai upaya untuk melindungi, mendukung dan mempromosikan pemberian ASI eksklusif. Peraturan tersebut menyebutkan pentingnya upaya untuk meningkatkan dukungan dari pemerintah, pemerintah daerah, fasilitas pelayanan kesehatan dan tenaga kesehatan, masyarakat serta keluarga agar ibu dapat memberikan asi eksklusif kepada bayi.Cakupan pemberian ASI eksklusif yang setiap tahun mengalami penurunan mengakibatkan rendahnya status gizi bayi. Rendahnya status gizi bisa mengakibatkan Kurang Energi Kronis (KEK) dan membuat bayi mudah terserang berbagai penyakit infeksi. Hasil laporan dari fasilitas pelayanan kesehatan terdapat jumlah kematian bayi di Provinsi Jambi tahun 2014 adalah 34 per 1000 kelahiran hidup (9). Pada tahun 2014 dari 6626 kelahiran bayi, terdapat 36 kematian pada balita (Profil Dinas Kesehatan Provinsi Jambi, 2015), dan pada tahun 2015 dari 6940 kelahiran bayi, terdapat 29 kematian pada balita. Hal ini dikarenakan masalah gizi, sanitasi dan penyakit infeksi. Pada tahun 2014 ditemukan 3 orang dengan masalah gizi buruk, dan pada tahun 2015 ditemukan 4 orang dengan masalah gizi buruk.

Persentase bayi yang diberikan ASI eksklusif di Provinsi Jambi pada tahun 2015 sebesar 55,69\%. Untuk pemberian ASI eksklusif tertinggi adalah Kabupaten Merangin sebesar 
95,15\% dan yang terendah adalah daerah Sungai Penuh sebesar 18,92\%. Kabupaten Bungo menduduki urutan kedua terendah di Provinsi Jambi dalam pemberian ASI eksklusif, dengan persentase sebesar 20,23\%.

Kabupaten Bungo merupakan salah satu Kabupaten yang ada diwilayah Provinsi Jambi yang memiliki Instansi Pemerintah Daerah (PEMDA) atau Satuan Kerja Perangkat Daerah (SKPD) sebanyak 56 instansi dengan jumlah ibu pekerja Pegawai Negeri Sipil (PNS) yang memiliki anak lebih dari 6 bulan sampai dengan 12 bulan sebanyak 48 orang.

Ibu bekerja sering dihadapkan pada suatu masalah, dimana ia harus meninggalkan bayinya untuk jangka waktu tertentu sehingga ibu dihadapi pada pilihan yang dilematik yaitu tetap menyusui bayinya atau bekerja untuk memenuhi kebutuhan ekonomi, tidak menyusui secara teratur atau tidak memberikan ASI sama sekali kepada bayinya. Berdasarkan hasil survey pendahuluan yang dilakukan peneliti dengan mengambil sampel 15 orang ibu yang mempunyai bayi 0-12 bulan di Kabupaten Bungo didapati tiga orang ibu mengetahui tentang ASI eksklusif dan menerapkannya dan berhasil menyusui secara eksklusif, delapan orang ibu memberikan ASI hanya sampai tiga sampai empat bulan saja dan ibu beralasan jumlah ASI tidak mencukupi sehingga ditambah dengan memberikan susu formula, tiga orang ibu memberikan susu formula ditambah dengan ASI karena sejak bayi lahir ditempat ibu bersalin telah memberikan susu formula dan satu orang ibu mengatakan sejak bayi lahir ibu memberikan susu formula karena menurut ibu susu formula merupakan nutrisi untuk bayi yang gizinya setara dengan ASI.

Oleh karena itu, melihat dampak yang bisa terjadi akibat rendahnya cakupan pemberian ASI Eksklusif dan berdasarkan dari hasil survey yang dilakukan, maka peneliti tertarik untuk meneliti tentang determinan pemberian ASI eksklusif pada ibu bekerja di Instansi Pemerintah Kabupaten Bungo Provinsi Jambi

\section{METODE PENELITIAN}

Penelitian ini merupakan penelitian kombinasi yaitu metode penelitian yang menggabungkan antara metode penelitian kuantitatif dan metode penelitian kualitatif (Sugiyono, 2014). Penelitian kuantitatif menggunakan desain cross sectional. Data variabel independen dan variabel dependen dikumpulkan dan dinilai dalam satu waktu. Kemudian penelitian kualitatif dilakukan untuk menggali informasi mendalam mengenai upaya pemberian ASI Eksklusif di Instansi Pemerintah Kabupaten Bungo Provinsi Jambi. Penelitian ini akan dilakukan di Instansi Pemerintah daerah
Kabupaten Bungo. Penelitian ini dilakukan pada bulan Maret - Juni 2018. Populasi dalam penelitian ini adalah Pegawai Negeri Sipil (PNS) wanita yang tercatat bekerja di Instansi Pemerintah Kabupaten Bungo Provinsi Jambi, mempunyai bayi berusia lebih dari 6 - 12 bulan yang berjumlah 50 orang. Sampel dalam penelitian ini adalah Pegawai Negeri Sipil (PNS) wanita yang tercatat bekerja di Instansi Pemerintah Kabupaten Bungo Provinsi Jambi yang memenuhi kriteria inklusi.

\section{HASIL DAN PEMBAHASAN}

Penelitian ini dilakukan di Instansi Pemerintah Kabupaten Bungo. Penelitian ini dilakukan terhadap 50 orang ibu yang mempunyai bayi lebih dari 6 bulan -12 bulan yang memenuhi kriteria inklusi dan eksklusi penelitian. Calon responden diberikan penjelasan tentang latar belakang, tujuan dan manfaat penelitian serta mendapatkan persetujuan tertulis dari subjek penelitian. Data yang diperoleh dari hasil penelitian dapat dilihat pada tabel berikut:

\section{Analisa Univariat}

\section{Variabel Dependen}

Tabel 1. Distribusi Frekuensi Responden Berdasarkan Pemberian ASI Eksklusif

\begin{tabular}{lll}
\hline ASI Eksklusif & $\mathrm{F}$ & $\%$ \\
\hline Tidak Eksklusif & 33 & 66 \\
Eksklusif & 17 & 34 \\
Total & 50 & 100 \\
\hline
\end{tabular}

Berdasarkan tabel 1 menunjukkan proporsi ibu bekerja di Instansi Pemerintah Kabupaten Bungo yang memberikan ASI eksklusif selama 6 bulan hanya $34 \%$.

\section{Variabel Independen}

Tabel 2. Distribusi Frekuensi Responden Berdasarkan

\begin{tabular}{lll}
\multicolumn{2}{c}{ Variabel Independen } & \\
\hline \multicolumn{2}{c}{ U } & $\%$ \\
\hline 20-35 tahun & 33 & 66 \\
>35 tahun & 17 & 34 \\
Paritas & & \\
$\quad$ Primipara & 6 & 12 \\
Multipara & 44 & 88 \\
Penolong Persalinan & & \\
$\quad$ Dokter & 34 & 68 \\
Bidan & 16 & 32 \\
Inisiasi Menyusu Dini (IMD) & & \\
$\quad$ IMD & 46 & 92 \\
Tidak IMD & 4 & 8 \\
Keterpaparan Informasi & & \\
Media Cetak & 4 & 8 \\
Media Elektronik & 7 & 14 \\
Media Papan & 2 & 4 \\
Petugas Kesehatan & 37 & 74 \\
Pengetahuan & & \\
Baik & 4 & 8 \\
Cukup & 20 & 40 \\
Kurang & 26 & 52 \\
Sikap & &
\end{tabular}




$\begin{array}{lll}\text { Negatif } & 22 & 44 \\ \text { Positif } & 28 & 56 \\ \text { Ketersediaan Fasilitas } & & \\ \quad \text { Tidak } & 47 & 94 \\ \quad \text { Ada } & 3 & 6 \\ \text { Dukungan Suami } & & \\ \quad \text { Tidak ada mendukung } & 7 & 14 \\ \quad \text { Ada Mendukung } & 43 & 86 \\ \text { Dukungan Petugas Kesehatan } & & \\ \quad \text { Tidak ada mendukung } & 4 & 8 \\ \quad \text { Ada Mendukung } & 46 & 92 \\ \text { Dukungan Atasan } & & \\ \quad \text { Tidak ada mendukung } & 7 & 14 \\ \quad \text { Ada Mendukung } & 43 & 86 \\ \text { Dukungan Pengasuh/Keluarga } & & \\ \quad \text { Tidak ada mendukung } & 28 & 56 \\ \text { Ada Mendukung } & 22 & 44\end{array}$

Dari tabel 2 dapat dilihat bahwa lebih dari separoh umur responden tidak berisiko $(66 \%)$, ibu multipara, persalinannya ditolong oleh dokter (68\%), mendapatkan informasi tentang ASI Eksklusif dari petugas kesehatan (74\%), berpengetahuan cukup (40\%), memiliki sikap yang positif (56\%), tidak ada dukungan dari pengasuh/keluarga $(56 \%)$, hampir seluruhnya melakukan IMD (92\%), tidak ada tersedia fasilitas $(94 \%)$, mendapatkan dukungan dari suami $(86 \%)$, atasan (86\%) dan petugas kesehatan (92\%).

\section{Analisa Multivariat}

Sebelum dilakukan uji multivariat, maka dilakukan penyaringan variabel independen dengan melihat nilai $p$ masing-masing variabel yang telah diuji secara bivariat. Dengan analisis logistik sederhana dimaksudkan untuk mencari kandidat variabel yang akan dimasukkan kedalam analisis regresi logistik berganda bentuk full model, dan ini dilakukan dengan tahapan berikut ini.

\section{Analisis Regresi Logistik Sederhana}

Analisis ini dimaksudkan untuk mencari kandidat variabel yang akan dimasukkan kedalam analisis logistik berganda bentuk full model, untuk itu dapat dilihat pada tabel berikut:

Tabel 3. Analisa Regresi Logistik Sederhana (Seleksi Bivariat)

\begin{tabular}{cccc}
\hline No & Variabel & $p$-value & $\begin{array}{c}\text { Masuk } \\
\text { Model }\end{array}$ \\
\hline 1 & Penolong Persalinan & 0.001 & + \\
2 & Dukungan & 0.000 & + \\
& Pengasuh/Keluarga & & \\
\hline
\end{tabular}

Hasil analisis bivariat menunjukkan bahwa tidak semua variabel mempunyai nilai $p<0,25$. Variabel yang masuk ke dalam multivariat yaitu penolong persalinan dan dukungan pengasuh/keluarga.

\section{Analisis Logistik Berganda Bentuk Full Model}

Dari hasil analisis logistic sederhana selanjutnya dilakukan analisis regresi logistik berganda bentuk full model:

Tabel 4. Regresi Logistik berganda Bentuk Full Model

\begin{tabular}{cccccc}
\hline Variabel & B & SE & Wald & Sig & Ekp $\boldsymbol{\beta}$ \\
\hline Penolong Persalinan & & 2,196 & 0.917 & 5,736 & 0,17 \\
Dukungan Pengasuh/Keluarga & 3,232 & 0,957 & 11,404 & 0,01 & 25,986 \\
\hline
\end{tabular}

Hasil analisis pada tabel menunjukkan bahwa dukungan pengasuh/keluarga merupakan faktor yang paling dominan terhadap pemberian ASI secara eksklusif dengan nilai $p<0,05$. Untuk melihat variabel mana yang paling besar pengaruhnya terhadap variabel independen, dilihat dari Exp ( $\beta$ ) Semakin besar nilai $\operatorname{Exp}(\beta)$ berarti semakin besar pengaruhnya terhadap variabel dependen. Nilai eksponen betha $(\exp \beta)$ paling besar pada variabel dukungan keluarga adalah 25,318 artinya jika dukungan keluarga bisa diterapkan dengan baik maka pemberian ASI eksklusif berpeluang 25 kali lebih baik.

\section{Hasil Penelitian Kualitatif}

Pengumpulan data kualitatif dilakukan dengan menggunakan wawancara mendalam dan focus grup discussion (FGD). Wawancara mendalam dilakukan kepada Kepala Badan
Kepegawaian Dan Pengembangan Sumber Daya Manusia Daerah Kabupaten Bungo, Kepala Dinas Kesehatan, Kepala Bidang Dinas Pendidikan, Sekertaris Dinas Sosial, Pemberdayaan Perempuan dan Keluarga Berencana, Pemberdayaan Perempuan dan Perlindungan Anak, Sekertaris Kecamatan Pelepat llir Kabupaten Bungo, Kepala Puskesmas Kuamang Kuning Unit X. FGD dilakukan pada 8 orang lbu PNS yang mempunyai bayi $>6$ bulan -12 bulan bekerja di Instansi Pemerintah Kabupaten Bungo. FGD dilakukan kepada responden yang sebelumnya telah mengisi kuesioner pada penelitian ini. Informan dalam penelitian ini berjumlah 14 Orang

\section{Karakteristik Informan}


Tabel 5. Karakteristik Informan dalam Pemberian ASI Eksklusif pada ibu PNS yang bekerja di Instansi Pemerintah Kabupaten Bungo

\begin{tabular}{|c|c|c|c|c|c|}
\hline Informan & Inisial & Umur (tahun) & Latar Belakang & Pendidikan & Metode \\
\hline 1 & WS & 40 & Kepala BKD PSDM & S1 & \\
\hline 2 & SM & 30 & Kepala Dinas Kesehatan & S2 & Wawancara \\
\hline 3 & $\mathrm{M}$ & 33 & Kepala Bidang Dinas Pendidikan & S2 & Mendalam \\
\hline 4 & DS & 40 & $\begin{array}{l}\text { Sekretaris Dinas Sosial, PP dan KB, } \\
\text { PP dan Perlindungan Anak }\end{array}$ & S1 & \\
\hline 5 & & 35 & Sekretaris Kecamatan Pelepat Ilir & S1 & \\
\hline 6 & $\mathrm{~S}$ & 21 & $\begin{array}{l}\text { Kepala Puskesmas Kuamang Kuning } \\
\text { X }\end{array}$ & S1 & \\
\hline 7 & NAY & 33 & lbu balita & D3 & \\
\hline 8 & Y & 37 & Ibu balita & S1 & \\
\hline 9 & UM & 38 & Ibu balita & S1 & \\
\hline 10 & A & 30 & Ibu balita & D3 & \\
\hline 11 & $\mathrm{H}$ & 33 & Ibu balita & S1 & FGD \\
\hline 12 & $\mathrm{~S}$ & 34 & Ibu balita & D3 & \\
\hline 13 & SL & 35 & Ibu balita & S1 & \\
\hline 14 & $\mathrm{H}$ & 33 & Ibu balita & S1 & \\
\hline
\end{tabular}

\section{HASIL DAN PEMBAHASAN Pembahasan Univariat}

Berdasarkan hasil penelitian yang dilakukan, menunjukkan bahwa proporsi pemberian ASI eksklusif ibu bekerja di Instansi Pemerintah Kabupaten Bungo sebanyak 34\%. Jumlah tersebut belum memenuhi target pemberian ASI eksklusif yang ditetapkan secara nasional oleh pemerintah yaitu $80 \%$ dari jumlah bayi yang ada di Indonesia.

Hasil penelitian Abdullah (2012) menyatakan bahwa proporsi pemberian ASI eksklusif di Kementerian Kesehatan sebanyak $62,5 \%$, masih banyak ibu yang tidak melakukan ASI eksklusif dan berhenti menyusui dengan alasan karena kembali bekerja. Ibu bekerja selain belum memahami tentang ASI eksklusif, dukungan instansi untuk menyediakan sarana dan fasilitas masih belum tersedia. Selain itu, peraturan tentang masa cuti melahirkan belum mendukung ibu untuk memberikan ASI secara eksklusif. Menurut Gibney et al.,(2008), faktorfaktor yang menyebabkan ibu tidak memberikan ASI Eksklusif pada ibu yang bekerja dikarenakan pengetahuan tentang menyusui yang benar, perlengkapan memerah ASI, dan dukungan tempat kerja. Masalah pada ibu bekerja dikarenakan tidak ada waktu untuk memberikan ASI secara langsung oleh karena itu ibu dapat menyimpan ASI yang telah diperah sebelumnya untuk diberikan kepada bayinya.

Lebih dari separoh umur responden tidak berisiko, ibu multipara, persalinannya ditolong oleh dokter, mendapatkan informasi tentang ASI Eksklusif dari petugas kesehatan, berpengetahuan cukup, memiliki sikap yang positif, mendapatkan dukungan dari suami, atasan, petugas kesehatan, lebih dari separoh ibu tidak ada dukungan dari pengasuh/keluarga, hampir seluruhnya melakukan IMD dan tidak ada tersedianya fasilitas yang menunjang ibu memberikan ASI eksklusif.

Hasil penelitian ini menunjukkan bahwa pemberian ASI eksklusif pada umur ibu 20-35 tahun lebih besar yaitu $39,4 \%$ dibanding pada umur ibu $<20$ atau $>35$ tahun yang hanya $23,5 \%$. Hal tersebut menunjukkan kecendrungan untuk lebih memberikan ASI eksklusif pada umur ibu 20-35 tahun.

ASI eksklusif adalah pemberian hanya ASI saja pada bayi baru lahir sampai usia 6 bulan, tanpa diberikan makanan tambahan dalam bentuk apapun terkecuali obat dan vitamin. Selama itu bayi tidak diberikan tambahan cairan atau makanan pendamping lain seperti susu formula, air jeruk, air teh, air gula, madu, air putih, pisang, papaya, bubur susu, biscuit, bubur nasi dan tim. Setelah bayi berumur 6 bulan baru mulai diberikan makanan pendamping ASI (MPASI). ASI dapat diberikan sampai anak berusia 2 tahun atau lebih.

Indonesia telah menerbitkan Peraturan Pemerintah Nomor 33 Tahun 2013 tentang pemberian ASI eksklusif sebagai upaya untuk melindungi, mendukung dan mempromosikan pemberian ASI eksklusif. Peraturan tersebut menyebutkan pentingnya upaya untuk meningkatkan dukungan dari pemerintah, pemerintah daerah, fasilitas pelayanan kesehatan dan tenaga kesehatan, masyarakat serta keluarga agar ibu dapat memberikan asi eksklusif kepada bayi.

Di dalam undang-undang nomor 13 tahun 2003 tentang ketenagakerjaan pasal 82, pekerja perempuan memperoleh cuti satu setengah bulan sebelum dan satu setengah bulan sesudah melahirkan. Ini berarti kemampuan ibu untuk senantiasa bersama-sama bayinya hanya $25 \%$ dari waktu eksklusif enam bulan.

Cakupan pemberian ASI eksklusif yang setiap tahun mengalami penurunan mengakibatkan rendahnya status gizi bayi. Rendahnya status gizi bisa mengakibatkan Kurang Energi Kronis (KEK) dan membuat bayi mudah terserang berbagai penyakit infeksi. Hasil laporan dari fasilitas pelayanan kesehatan terdapat jumlah kematian bayi di Provinsi Jambi, hal ini dikarenakan masalah gizi, sanitasi dan penyakit infeksi. Pada tahun 2014 ditemukan 3 orang dengan masalah gizi buruk), dan pada 
tahun 2015 ditemukan 4 orang dengan masalah gizi buruk.

\section{Pembahasan Multivariat}

Hasil penelitian pada seleksi bivariat ditemukan 2 variabel yang akan menjadi kandidat pada uji selanjutnya yaitu uji regresi dimana variabel tersebut adalah penolong persalinan dan dukungan pengasuh/keluarga.

Hasil analisis pada tabel menunjukkan bahwa dukungan pengasuh/keluarga merupakan faktor yang paling dominan terhadap pemberian ASI secara eksklusif dengan nilai $p<0,05$. Untuk melihat variabel mana yang paling besar pengaruhnya terhadap variabel independen, dilihat dari exp (B). Semakin besar nilai exp (B) berarti semakin besar pengaruhnya terhadap variabel dependen. Nilai eksponen betha $(\exp B)$ paling besar pada variabel dukungan keluarga adalah 25,318 artinya jika dukungan keluarga bisa diterapkan dengan baik maka pemberian ASI eksklusif berpeluang 25 kali lebih baik.

Dukungan keluarga adalah dukungan yang diberikan oleh anggota keluarga (suami, istri, dan saudara) sehingga individu yang diberikan dukungan merasakan bahwa dirinya diperhatikan, dihargai, mendapatkan bantuan dari orangorang yang berarti serta memiliki ikatan keluarga yang kuat dengan anggota keluarga yang lain (Lubis, Namora \& Hasnida, 2009). Individu yang memperoleh dukungan keluarga yang tinggi akan menjadi individu yang lebih optimis dalam menghadapi masalah kesehatan dan kehidupan dan lebih terampil dalam memenuhi kebutuhan psikologi.

Menyusui anak mendorong solidaritas dan kerjasama antara kaum wanita pada tingkat rumah tangga, masyarakat luas, nasional maupun internasional. Pada tingkat rumah tangga, penyusuan yang sukses membutuhkan bantuan orang lain, kerabat atau kenalan yang dapat membantu dalam tugas-tugas rumah tangga.

Dukungan emosi dari lingkungan dan juga keluarga akan membantu dalam mengatasi rasa frustasi yang menjalar, menemani ibu bila terlihat kesepian, ikut menyanyangi anaknya, menanggapi dan memperhatikan kebahagian ibu. Serta menghibur bila ibu terlihat sedih. Anggota keluarga yang lain harus dilibatkan dalam tiap konseling, sehingga dapat dibangun pemahaman dari orang-orang terdekat ibu terhadap apa yang dirasakan dan dibutuhkannya.

Berbagai perasaan dapat muncul karena ibu terpaksa meninggalkan bayi dirumah, seperti perasaan tidak tega, berat, kasihan dan rasa penyesalan karena harus bekerja. Beberapa hambatan yang dirasakan ibu bekerja dalam praktik menyusui secara ekslusif adalah jarak rumah yang jauh, tidak ada fasilitas ditempat kerja, ASI sedikit, terbatasnya waktu bersama anak agar ibu dapat menyusui bayinya dan dukungan motivasi dari atasan, suami serta pengasuh/ keluarga yang menjaga bayinya..

Hasil penelitian ini menunjukkan bahwa ibu yang mendapatkan dukungan dari pengasuh/ keluarga akan berhasil melakukan pemberian ASI eksklusif, karena tanpa komitmen dan bantuan dari pengasuh/keluarga maka ASI eksklusif tidak akan berhasil mengingat ibu yang bekerja banyak waktu yang dihabiskan diluar rumah. Ibu bekerja harus mempunyai kesabaran dan ketekunan dalam memerah dan memberikan ASI perah kepada bayi mereka ketika ditinggal bekerja. Sudah seharusnya aktivitas ibu bekerja di luar rumah bukan dijadikan alasan untuk menghentikan pemberian ASI, namun menjadi sebuah motivasi untuk dapat memberikan ASI secara eksklusif bahkan mempertahankannya hingga 2 tahun.

\section{Pembahasan tentang perencanaan, pengorganisasian, pelaksanaan dan evaluasi tentang pemberian ASI eksklusif}

Persiapan dalam pemberian ASI eksklusif dipengaruhi dari berbagai hal, seperti sarana dan prasarana, dukungan dari berbagai pihak serta motivasi dari ibu itu sendiri. Pemberian ASI eksklusif di Kabupaten Bungo belum seperti yang diharapkan, hampir seluruh instansi nya tidak memiliki ruang pojok ASI dan belum adanya aturan yang jelas terhadap ibu-ibu yang sedang menyusui seperti PERDA bahkan tidak adanya penyuluhan dan supervisi tentang ASI eksklusif ke setiap Instansi pemerintah yang ada di Kabupaten Bungo. Tidak adanya penyuluhan dan tidak adanya penegasan dari kepala Dinas kesehatan untuk petugas penyuluhan. Supervisi dan penyuluhan di setiap Instansi yang ada di Kabupaten Bungo tidak berjalan dengan baik, karena alokasi dana hanya di dialokasikan di Puskesmas untuk penyuluhan langsung ke masyarakat, seperti penyuluhan pada posyandu dan penyuluhan langsung kemasyarakat, padahal ibu yang bekerja rata-rata tidak sempat datang ke posyandu, karena waktu dan pekerjaan mereka, sehingga mereka hanya datang ke pelayan kesehatan jika waktunya imunisasi bayinya dan jika ada gangguan kesehatan.

Hasil penelitian yang dilakukan oleh $\mathrm{O}^{\prime}$ Brien et. Al (2008), dikatakan bahwa strategi keberhasilan dalam pemberian ASI eksklusif dipengaruhi oleh kepercayaan diri ibu, pikiran positif, mampu mengatasi masalah, pencapaian tujuan dan keberhasilan dalam pelaksanaannya.

Untuk menjamin agar hak ibu menyusui terlaksana, negarapun memberikan kewajiban kepada setiap instansi dan perusahaan agar mendukung ibu menyusui. Bentuk dukungan tersebut dengan memberikan waktu dan fasilitas yang layak bagi ibu untuk menyusui bayinya. Masih banyaknya tempat kerja yang belum 
memiliki fasilitas khusus bagi ibu menyusui. Karena tak memiliki ruangan khusus menyusui, tak jarang para ibu ini harus menempati gudang, ruang arsip, ruangan disudut kantor, musholla bahkan di toilet. Tentu ruangan ini jauh dari nyaman dan memiliki privasi. Di ruanganruangan tersebut, menyusui bayi harus dilakukan cepat-cepat karena khawatir ada orang yang sedang mengantri atau bisa saja tiba-tiba ada orang yang masuk.

Secara umum sarana dalam program ASI eksklusif belum dapat mendukung pelayanan maupun penyuluhan kepada ibu hamil dan ibu menyusui secara optimal karena tidak adanya poster, leaflet, ruangan laktasi. Upaya pemenuhan kebutuhan sarana dan prasarana menunggu realisasi dari anggaran pemerintah daerah.

Pelaksanaan program ASI eksklusif di Instansi pemerintah KAbupaten Bungo belum dilaksanakan dengan baik yang dibuktikan oleh pernyataan semua informan menyatakan bahwa sarana dan prasarana yang belum ada dan belum lengkap. Sarana Prasarana yang tersedia belum mendukung pelaksanaan program ASI eksklusif. Sarana dan prasarana seperti tempat untuk melaksanakan pelayanan konseling laktasi atau ruangan laktasi belum tersedia.

Oleh karena itu perlunya sosialisas regulasi tentang ASI eksklusif melalui upaya KIE dan pemberian sanksi yang tegas bagi institusi terutama sarana kesehatan yang belum menerapkannya, peningkatan sarana pemberian ASI melalui penyediaan anggaran khusus program ASI eksklusif dan upaya peningkatan kapabilitas petugas melalui peningkatan tugas pokok dan fungsi serta pemahaman tentang standar operasional prosedur, serta perlunya peningkatan kinerja Dinas Kesehatan dalam hal menyukseskan program ASI Ekslusif dengan tujuan meningkatkan pengetahuan masyarakat tentang ASI ekslusif. Hal ini dapat dilakukan dengan mengadakan penyuluhan, praktek yang dipandu oleh petugas kesehatan yang terlatih dan memeriksa sarana dan prasarana yang mendukung pemberian ASI eksklusif.

Dukungan informasi dalam tata cara memerah, menyimpan, dan memberikan ASI perah dapat diakses informan dari tenaga kesehatan maupun media-media. Dukungan informasi tersebut didapat informan dari tenaga kesehatan dan media sosial. Oleh karena itu, perlu disediakan konseling menyusui bagi ibu bekerja

Indonesia telah menerbitkan Peraturan Pemerintah Nomor 33 Tahun 2013 tentang pemberian ASI eksklusif sebagai upaya untuk melindungi, mendukung dan mempromosikan pemberian ASI eksklusif. Peraturan tersebut menyebutkan pentingnya upaya untuk meningkatkan dukungan dari pemerintah, pemerintah daerah, fasilitas pelayanan kesehatan dan tenaga kesehatan, masyarakat serta keluarga agar ibu dapat memberikan asi eksklusif kepada bayi. Pengurus tempat kerja dan penyelenggara tempat umum wajib menyediakan fasilitas khusus ini sesuai dengan kemampuan tempat kerja

lbu dengan pemahaman yang rendah dapat memunculkan pendapat bahwa ASI nya tidak cukup, menyusui mengurangi keindahan tubuh dan lain-lain yang mendorong ibu sehingga ibu tidak memberikan ASI eksklusif. peran tenaga kesehatan akan sangat berarti pada kelompok ibu dengan pemahaman seprti ini.

Hasil penelitian Rojjanasrirat dalam Fauzie (2006), mengidentifikasi masalah fasilitas pendukung laktasi yang kurang tersedia, beberapa diantaranya adalah tidak tersedianya pompa ASI, tidak ada ruangan yang memadai untuk memerah ASI, tidak tersedia lemari pendingin untuk menyimpan ASI dan tidak cukup waktu luang untuk memerah ASI selama jam kerja.

Pelaksanaan program ASI eksklusif di Instansi Pemerintah Kabupaten Bungo belum dilaksanakan dengan baik karena proporsi pemberian ASI eksklusif hanya $34 \%$. Pernyataan semua informan yang menyatakan bahwa sarana dan prasarana yang tidak ada dan belum memadai. Sarana Prasarana yang tersedia belum mendukung pelaksanaan program ASI eksklusif. Sarana dan prasarana seperti tempat untuk melaksanakan pelayanan konseling laktasi atau ruangan laktasi, kulkas dan sarana penunjang yang lain belum tersedia di setiap Instansi serta supervisi dan penyuluhan yang dilakukan oleh Dinas Kesehatan.

Pada penelitian ini, pemberian ASI eksklusif tidak dilaksanakan dengan baik oleh ibu dikarenakan ibu telah memberikan susu formula saat bayi berumur $<6$ bulan. Menurut alasan responden jumlah ASI yang sedikit, waktu menyusui yang terbatas dan anggapan ibu bahwa pemberian susu formula sama seperti kandungan yang ada di dalam ASI.

Iklan susu formula di Indonesia sangat menarik perhatian ibu-ibu, padahal risiko susu formula bisa dirasakan langsung maupun tidak langsung seperti diare, muntah, alergi, diabetes, kanker, infeksi saluran cerna, gigi karies, kelebihan berat badan, daya tahan tubuh lemah, meningkatkan risiko asma dan menghambat perkembangan kognitif pada bayi.

Kebanyakan ibu di Indonesia akan merasa bangga bila memiliki bayi yang bertubuh gemuk atau gendut, karena dianggap sehat, lucu dan menggemaskan. Padahal, kondisi kelebihan berat badan baik overweight maupun obese berarti terjadi penumpukan lemak sehingga memiliki risiko penyakit. Walaupun pada komposisi dikatakan bahwa susu formula mengandung $90 \%$ susu sapi, tetap saja susu 
formula mengandung bahan kimia yang berbaha bagi kesehatan bayi. Tanpa adanya campuran bahan kimia, tidak mungkin susu formula dapat tahan satu hingga dua tahun kemudian. Semahal apapun susu formula tersebut, tetap saja akan ada campuran bahan pengawet agar komposisi susu masih bagus sampai waktu yang ditetapkan, bahkan susu formula juga bisa dikonsumsi dengan varian rasa. Perlu adanya perubahan pemahaman di masyarakat bahwa anak yang gemuk belum tentu sehat. Apapun kandungan susu formula, tidak ada yang dapat mengalahkan asupan gizi dalam ASI.

Keterbatasan ruangan menjadi kendala sehingga tidak bisa untuk melakukan laktasi. Selama ini ibu-ibu pulang kerumah tanpa ada evaluasi dari atasan terhadap pegawainya karena tidak adanya aturan yang tetap mengenai ibu-ibu yang sedang menyusui, sehingga atasan tidak mengontrol kapan lbu datang kembali untuk bekerja ketika ibu permisi untuk menyusui, sehingga terganggunya layanan kepada masyarakat yang sedang memerlukan karena tidak adanya petugas (ibu pekerja) akibat tidak adanya sarana dan prasarana yang mendukung pemberian ASI eksklusif.

Hasil penelitian Afriana (2004) menunjukkan, ibu berhenti untuk menyusui bayinya dengan alasan bekerja (32,5\%). Temuan ini sesuai dengan Kementerian Kesehatan (2010) yang menyatakan bahwa masih banyak ibu yang berhenti menyusui dikarenakan kembalinya ibu untuk bekerja. Ibu bekerja selain tidak memahami menyusui eksklusif, sebagian besar tempat kerja tidak menyediakan sarana dan fasilitas menyusui. Selain itu, peraturan mengenai masa cuti melahirkan belum mendukung pemberian ASI eksklusif.

Kedepannya perlu adanya aturan yang jelas mengenai ibu menyusui dari peraturan daerah Kabupaten Bungo, supervisi, penyuluhan dan bimbingan teknis terhadap pelaksanaan pemberian ASI eksklusif ke setiap instansi, komitmen dan kepedulian dari Dinas Kesehatan sehingga ASI eksklusif dapat berjalan dengan lebih baik sehingga capaian target terpenuhi.

\section{SIMPULAN}

Cakupan pemberian ASI eksklusif belum mencapai target $80 \%$ dari target yang ditetapkan Pemerintah dikarenakan kurangnya dukungan dari Instansi Pemerintah, petugas kesehatan dan dari pengasuh/keluarga. Perlu berbagai upaya untuk meningkatkan pencapaian cakupan pemberian ASI eksklusif khususnya melalui sarana penunjang untuk mendukung pemberian ASI eksklusif dan optimalisasi peran Dinas Kesehatan.

\section{DAFTAR PUSTAKA}

Kementerian Kesehatan RI. Strategi Peningkatan Makanan Bayi dan Anak (PMBA). Jakarta: Kemenkes RI. 2010

Suradi, R., Roesli, U. 2006. Manfaat ASI dan Menyusui. Jakarta : Fakultas Kedokteran Universitas Indonesia.

World Health Organization (WHO). 2011"Breastfeeding-Exclusive".

http:www.who. int/elena. Diakses 17 Oktober 2017.

UNICEF. Sehatan Anak. Jakarta: BKKBN BPS, and Young Child Feeding Counselling Packageack. 2012

Undang-Undang Republik Indonesia (2009). Undang-undang RI No 36 Jakarta: Rineka Cipta

Kemenkes RI. Profil Kesehatan Indonesia tahun 2014. Jakarta : Kemenkes Rl; 2015

Rohani. 2010. " Faktor-faktor yang meningkatkan risiko kegagalan pemberian ASI eksklusif pada ibu bayi usia 6-9 bulan di Kota Mataram Provinsi Nusa Tenggara Barat". Tesis. Program Pascasarjana. Universitas Udayana. Bali

Dinas Kesehatan Kota Padang (2016) . Profil Kesehatan Kota Padang 2015. Padang: Dinas Kesehatan Kota Padang

Sugiyono. (2014). Metode Penelitian Kuantitatif, Kualitatif dan R\&D. Bandung:

IDAI. ASI Eksklusif Pada lbu Yang Bekerja.

Rizani (2009) faktor faktor yang berhubungan dengan prilaku ibu dalam pemberian ASI 2011. Diploma thesis, universitas andalas

Notoatmodjo, Soekidjo (2010). PROMOSI KESEHATAN Teori \& Aplikasi. Penerbit PT Adi Mahasatya: Jakarta

Azwar S., 2008 Sikap Manusia Teori dan Pengukurannya. Jakarta : Pustaka Pelajar

Notoatmodjo,S. 2012. Metodologi Penelitian Kesehatan. Jakarta: Rineka Cipta. . 2004. Metodologi Penelitian Kesehatan. Jakarta: Rineka Cipta

Dinkes Kabupaten Bungo. 2017. Laporan Tahunan Seksi Kesehatan. Kabupaten Bungo 